\title{
The Self-Efficacy as Predictors of the Metacognition Awareness in Children
}

\author{
Kayhan Bozgün*
}

\author{
Serpil Pekdoğan**
}

\begin{abstract}
It is important for children to have some skills and competencies in the acquisition of effective learning skills. Metacognition awareness that allow children to become aware of what they know and think to learn a knowledge and build on the knowledge they will learn in this process; they need to be self-efficacy in order to accomplish a task and to be able to come up with new problems or situations. In this context, the research aimed to determine whether self-efficacy in children predicts metacognition awareness, and also the results of the relationship between self-efficacy and metacognition and the validity and reliability of the measurement tools used are included in the study. In the research, the correlational survey model, which is one of the quantitative research method, is used to determine the relationship between two or more variables. The study group of this study consists of 350 children aged between 12 and 14 years, continuing to middle schools which are depends on Ministry of National Education in Turkey. The Personal Information Form, "Self-Efficacy Scale for Children" and "Scale of Metacognition for Children" were used together to collect the data of the study. The reliability coefficients of the measuring instruments were determined with the Cronbach alpha coefficient, after the fitting of the measuring instruments used in the study was confirmed on the working sample. The Cronbach's alpha coefficient for the self-efficacy scale for children were calculated .88; and the Cronbach's alpha coefficient for the metacognition scale for children were calculated as .92. To investigate the relationship between self-efficacy and metacognition awareness, the Pearson Moments Multiplication Correlation Coefficient is calculated and confirmatory factor analysis was used to check the fit of the scales with the sample group. It has been determined that self-efficacy is a predictor of metacognition awareness according to the results of multiple regression to examine whether self-efficacy beliefs in children are predictive of metacognition awareness. The development of metacognition and self-efficacy levels together in children is one of the issues to be emphasized by parents and educators.
\end{abstract}

Keywords: metacognition awareness, self-efficacy, children, learning styles

\footnotetext{
Res. Assist., Amasya University, Faculty of Education, Primary Education Program, Amasya, Turkey. E- Mail: kayhanbozgun@gmail.com ORCID ID: 0000-0001-9239-2547

** Assist. Prof. Dr., Hitit University, School of Health, Department of Child Development, Çorum, Turkey. E-mail: serpilpekdogan.sp @ gmail.com ORCID ID: 0000-0002-8442-354X
} 


\title{
Çocuklarda Üstbiliş Farkındalığının Yordayıcısı olarak Özyeterlik
}

\begin{abstract}
$\ddot{\mathbf{O} z}$
Çocuklar için etkili öğrenme becerilerinin edinilmesi konusunda bazı becerilere ve yetkinliklere sahip olmak önemlidir. Çocukların bir bilgi edinmek için bildikleri ve düşündüklerinin farkında olmalarını sağlayan ve bu süreçte öğrenecekleri bilgiyi geliştiren üstbiliş farkındalığına; bir görevi yerine getirmek ve yeni sorunlar veya durumlarla karşılaşabilmek için de öz yeterlik becerilerine sahip olmaları gerekir. Bu bağlamda, araştırmanın amacı, çocukların öz yeterliklerinin üstbiliş becerilerini yordayıp yordamadığını ve öz yeterlik ile üstbiliş arasındaki ilişkinin sonuçlarını ve kullanılan ölçüm araçlarının geçerlik ve güvenilirliğini araştırmaktır. Araştırmada yöntem olarak nicel araştırma yöntemlerinden olan, iki veya daha fazla değişken arasındaki ilişkiyi belirlemeyi sağlayan ilişkisel tarama deseni kullanılımıstır. Yaşları 1214 arasında değişen Türkiye'de Millî Eğitim Bakanlığına bağlı ortaokullara devam eden 350 ortaokul öğrencisi bu çalışmanın çalışma grubunu oluşturmaktadır. Çalışmanın verilerini toplamak için Kişisel bilgi formu, "Çocuklar için Özyeterlik Ölçeği” ve "Çocuklar için Bilişüstü Ölçeği” kullanılmıştır. Çalışmada kullanılan ölçme araçlarının çalışlan örneklem üzerindeki uyumu saptandıktan sonra, ölçme araçlarının güvenirlik katsayılarına Cronbach Alpha katsayısı ile bakılmıştır. Çocuklar için özyeterlik ölçeğinin Cronbach Alfa katsayısı .88; çocuklar için bilişüstü ölçeğinin güvenirlik katsayısı .92 olarak haesaplanmıştır. İki ölçek aras ındaki ilişkiyi belirlemek için Pearson Momentler Çarpımı Korelasyon Katsayısı hesaplanmış; ölçeklerin örneklem grubu ile uyumunu kontrol etmek için doğrulayıcı faktör analizi kullanılmıştır. Çocuklardaki özyeterlik becerilerinin üst biliş becerilerinin yordayıcısı olup olmadığını belirlemek için gerçekleştirilen çoklu regresyon sonuçlarına göre özyeterlik becerileri üstbilişin bir yordayıcıs1 olduğu bulgularına ulaşılmıştır. Çocuklarda üstbiliş ve özyeterlik becerilerinin birlikte gelişimi aileler ve eğitimciler tarafindan önemle üzerinde durulması gereken konular arasinda yer almalidır.
\end{abstract}

Anahtar Sözcükler: üstbiliş farkındalığı, özyeterlik, çocuklar, öğrenme stilleri 


\section{Introduction}

Children need to have some skills and competencies to gain effective learning skills. It is the metacognition awareness that allow children to be aware of what they know and think to learn a knowledge, and build on this process experience on the knowledge they will learn; they need to have acquired personal qualifications to achieve a job and to be able to overcome new problems or situations (Flavell, 1976; Thomas et al., 2008). What matters first is that the child should aware of the information that the child has already acquired so that the child's learning can be healthy.

Metacognition, have such great effect on learning, first described by Flavell (1976) as being aware that one knows his cognitive processes and knowledge in a subject (Coutinho, 2008; Thomas, Anderson and Nashon, 2008). According to this definition, the person takes responsibility for the information he learns; and he plans, monitors and evaluates that information. Besides the definition of Flavell, another definition of metacognition, which is frequently used in the literature, is defined by Hacker (1998), as well as knowing the person's knowledge, process, cognition and situation, this process has the ability to monitor and manage cognition and situations. According to the definitions that are made in a different but units in common point, metacognition can be explained as knowing what the learner knows, monitoring and controlling the learning process, evaluating himself / herself and learning process.

Flavell (1976) acknowledges that metacognition consists of two strategies: monitoring and regulation. Monitoring consists of self-testing skills necessary to ensure that learning is controlled (Schraw, Crippen and Hartley, 2006). Regulation consists of skills that enable the person to plan, interpret and self-assess using existing approaches, steps, and effective resources (Balcikanli, 2011; Cheng, 2011; Kaplan and Duran, 2015; Schraw 2001). After Flavell's (1976, 1979) studies to conceptualize and to define the structure of the metacognition, the significiance of the metacognition was noticed by the researchers and the studies for the development and identification of the metacognition levels of the students continued increasingly (Thomas et al., 2008).

As a result of developing and adapting metacognition strategies of children, it can be made their learning more permanent. Metacognition enables children to be aware of their strategies to control and know how to accomplish a job (Cera, Mancini and Antonietti, 2013). The importance of metacognition in explaining, discovering, and improving the thinking and learning processes of the learners is also frequently discussed (Thomas and McRobbie, 2001). In the realization of effective learning, the self-efficacy of the children is as important as the acquisition of metacognition strategies.

The realization of learning in education is not only provided by family, teacher, school; at the same time, the learner must also have a willingness to learn. The acquisition of this desire or motivation that children should have at primary education level can also be achieved by the high level of self-efficacy, which consists of factors such as belief, desire to achieve, determination and completeness of the process. By its most general definition selfefficacy can be expressed as having the motivation, determination, confidence, and selfcontrol skills that a student must have before beginning a task to be done or completed (Bandura, 1993; Cera, Mancini ve Antonietti, 2013).

Bandura (1993), who theorizes the Social Cognitive Learning Theory, describes selfefficacy as positive self-beliefs about the ability of a person to control and handle behavior in a job or event. Ridlo and Lutfia (2017) explain the self-efficacy, as the achievement of the level of confidence that children should have in order to successfully complete the lessons; Zakeri, Rahmany and Labone (2016), on the other hand, described the combination of continuity, effort, efficiency and success required to organize, plan and complete a business. As it is understood from these definitions, the acquisition of self-efficacy is as important as the acquisition of metacognition awareness when the learning takes place in an effective way.

One of the most important educational goals that children in primary education must achieve is knowing how to complete a task on their own (Cera et al., 2013). In addition, academic success of children depends on their high self-efficacy levels. Children who want 

CHILDREN

to successfully complete a job or situation that they have been thinking about may become worried about the work they will do as they become less confident and wipe out to produce a solution to failure. The children can accomplish their task more easily if they believe that they will do the job, and can complete the task by finding the necessary self-confidence. Based on this information, Bassi, Stea, Fave and Caprara (2007) reported that students with high self-efficacy had higher academic goals and efforts than those with low self-efficacy.

With the use of metacognition awareness such as planning, controlling, monitoring and evaluation for the resolution of the problems encountered, children with self-efficacy who need to be committed and convinced to accomplish, can solve problems and fulfill responsibilities without any problems. In this context, metacognition and self-efficacy are two factors that play a role in organizing and planning children's work and learning effectively. Schraw et al. (2006) have expressed that the strategies used by students and the metacogniton are sub-classes of self-efficacy, and there is a relationship between metacognition and self-efficacy. Self-efficacy also increases as the level of metacognition increases. Ridlo and Lutfia (2017) stated that children will be confronted with situations of success and failure to use metacognition strategies in response to their confidence and weakness in their duties. It can be deduced that this relationship is an inseparable link between metacognition and self-efficacy, and that the level of self-efficacy must be increased in order to increase the level of metacognition in a child.

In literature, there are a number of studies have examined the relationship between metacognition and self-efficacy (Cera et al., 2013; Coutinho, 2008; Moores, Chang, \& Smith, 2006; Ridlo and Lutfiya, 2017; Schraw et al, 2006). In these studies it is understood that these two variables are independent of each other but can not be thought separated from each other. When children with high metacognition awareness were examined, self-efficacy levels in these children were found to be high. Likewise, when children with high selfefficacy levels are examined, the likelihood that these children have more metacognition awareness is striking. When looking at the studies done in the literature, it is seen that studies that study the relation between metacognition awareness and self-efficacy of children are discussed in the international literature, but in Turkey, although there are many studies related to adults such as adolescents, teacher candidates etc.; it has been seen that there is no such work for children. It is expected that parents and teachers and other educators who are responsible for the education of the children will learn the relationship between self-efficacy and metacognition in the learning of the child and that these factors will be given to the children to achieve effective and permanent learning. This study was conducted to determine whether self-efficacy in children is predictive of metacognition awareness. For this purpose, the following questions were sought;

- What are the findings regarding the validity and reliability of the "Self-Efficacy Scale" and the "Metacognition Scale" for children in this study?

- Is there a relationship between children's metacognition awareness and self-efficacy?

- Are children's metacognitive awareness predicting self-efficacy?

\section{Method}

\section{Design of the Study}

The research was designed in the correlational survey model. Correlational survey models are research models aimed at determining the presence and degree of variation between two or more variables (Gay, 1987). Representations in the correlational survey model (the task of determining the values of the properties) are intended to identify distinctions between children, objects and etc., rather than trying to find measures that meet certain standards. (Gall, Gall and Bord 1999; Cohen, Manion and Morrison, 2000).

\section{Participants}

Children in the 12-14 age range are included in the study because they are cognitively in the process of transactions and know how to complete a job on their own. According to Kline (2005), the sample should be 10 times the number of items, and the number of samples should not be less than 200 . Therefore, for the validity and reliability of the study, the sample group consisted of 240 children aged 12-14 years who continuing to secondary school. 
However, 350 children were included in the study group for the actual study. The study consisted of $178(\% 50.9)$ girls and $172(\% 49.1)$ boys; and $122(\% 34.9)$ children are 12 years old and $123(\% 35.1)$ are 13 years old and $105(\% 30)$ are 14 years old. Demographic information is given in Table 1 .

Table 1. Demographic information of the children participating in the study

\begin{tabular}{llll}
\hline Variables & Sub-categories & $\mathrm{n}$ & $\%$ \\
\hline \multirow{2}{*}{ Age } & 12 & 122 & 34.9 \\
& 13 & 123 & 35.1 \\
& 14 & 105 & 30 \\
\hline \multirow{2}{*}{ Gender } & Girl & 178 & 50.9 \\
& Boy & 172 & 49.1 \\
\hline
\end{tabular}

\section{Data Collection Tools}

The data of the study were collected by "The Self-Efficacy Scale for Children", "The Metacognition Scale for Primary School Students" and "Personal Information Form".

The Self-Efficacy Scale for Children: The Self-Efficacy Scale for Children was developed by Muris (2001) with the aim of measuring social, academic and emotional selfefficacy of adolescents aged 12-19 years. The adaptation of the scale to the Turkish was carried out by Telef and Karaca (2012). Correlations between the Turkish and English forms of The Self-Efficacy Scale for Children were found .95 for the general population; sub factors were found to be .93 for academic self-efficacy; .94 for social self-efficacy and .91 $(p<.01)$ for emotional self-efficacy. As a result of exploratory factor analysis, it was found that the total explained variance was $\% 43.74$ and the items were collected under 3 factors. When the eigenvalues with respect to the factor covariance of scale's items were examined, they were found to be between .30 and .59. In the confirmatory factor analysis, the consistency index values were found as $x^{2} / s d=614.68 / 186=3.31$; RMSEA=.05; NFI=.95; $\mathrm{CFI}=.96 ; \mathrm{GFI}=.94$ and $\mathrm{RMSR}=.07$. In the discriminant validity study of the scale, an upperlower \% 27 group comparison was made. It was seen that the test values obtained varied between 10.98 and 21.17 and all the items $(p<.01)$ were meaningful. When the internal consistency coefficients of The Self-Efficacy Scale for Children were examined, it was calculated as .86 for the general scale, sub-factors were found .84 for the academic selfefficacy; .64 for the social self-efficacy and .78 for the emotional self-efficacy. The testretest reliability coefficients of the scale ranged from .75 to .89 . The General Self-Efficacy Scale was used to look at the criterion-dependent validity of The Self-Efficacy Scale for Children. The Pearson Moments Multiplication Correlation was found to be $.57(p<.01)$ among the scores obtained from the application of the two scales. The Self-Efficacy Scale for Children is a scale of five point Likert type (1=no and 5=very good). Total self-efficacy are calculated by adding related items in sub-factors scores. The highest score on the scale is 105 and the lowest score is 21 . The high score from the scale indicates that the relevant selfefficacy level of the children is high and the low score from the scale indicates that the selfefficacy level of the children is low.

The Metacognition Scale for Primary School Students: The Metacognition Scale was developed by Yildı, Akpinar, Tatar and Ergin (2009) in order to measure the students' metacognition perceptions and awareness. An exploratory and confirmatory factor analysis was performed by the researchers who developed the scale to ensure that the scale is valid. The Cronbach Alpha reliability coefficient of the scale of 30 items was found to be .96. The scale consists of sub-factors that address the two basic dimensions of metacognition: cognitive knowledge and regulation of cognition. These factors include "explanatory knowledge (9 items)", "methodological knowledge (4 items)", "conditional knowledge (4 items)" for cognitive knowledge dimension; "planning (2 items)", "self-control (3 items)", cognitive strategy (3 items), self-evaluation (3 items), and self-monitoring (2 items) for regulation of cognition dimension. The lowest score that can be taken from the scale is 30 and the highest score is 120 . The Cronbach alpha internal consistency coefficient for the whole scale was calculated as .96 . 

CHILDREN

\section{Analysis of Data}

In the analysis of the data, the validity analysis of the measurement instruments used firstly was done. In this context confirmatory factor analysis was used. Confirmatory factor analysis (CFA) is used to check whether the pre-selected factor model has been adjusted for consistency. Confirmatory factor analysis is very useful in the development, organization and re-evaluation of measurement tools (Floyd and Widaman, 1995). Therefore, the compatibility of the data was tested with the LISREL 8.80 packet program to determine whether the data in the investigator's data conformed to the original structure. The reliability coefficients of the measuring instruments were determined with the Cronbach Alpha coefficient, after the fitting of the measuring instruments used in the study was confirmed on the working sample. The data were processed into the SPPS 20.0 program and after the validity and reliability of the measurement tools were given, it was observed whether there were extreme values before the analysis and the regression analysis was deemed to meet the assumptions of "linearity" and "multivariate normality". The graph of standardized dependent values with standardized deviations values showed that the assumption of linearity was met. It is seen that there is no significant deviation from the normal distribution in the graph of the observed and expected cumulative probability distribution, plotted with respect to the standardized deviation values. Pearson correlation coefficient analysis was used to determine whether there is a meaningful relationship between metacognition awareness and self-efficacy; and multiple regression analysis was used to determine selfefficacy as a predictor of metacognition awareness. The findings were assessed at a significance level of .05. Multiple regression analysis allows estimation of the dependent variable based on two or more independent variables associated with dependent variables (Büyüköztürk, 2010).

\section{Findings}

\section{Findings related to Validity and Reliability}

\section{Findings about the Self-Efficacy Scale for Children}

When the findings of confirmatory factor analysis made to test the fit of the selfefficacy scale for children with the original structure on the sample group studied were examined, the ratio of $x^{2} / s d$ was found to be $2.51\left(x^{2} / s d=467.93 / 186\right)$. Looking at the ratio of degrees of freedom with Chi-Square, it is seen that it has a value of under 3 and thus this value indicates a good consistency value (Hooper, Coughlan ve Mullen, 2008; SchermellehEngel, Moosbrugger ve Müller, 2003). Other consistency index values calculated with CFA are CFI: 0.95, GFI: 0.89, AGFI: 0.86, NFI: 0.92; NNFI: 0.95; RFI: 0.95. When these values are close to 1, it is considered as a acceptable consistency (Baumgartner \& Homburg, 1996; Bentler, 1980; Bentler \& Bonett, 1980; Marsh, Hau, Artelt, Baumert \& Peschar, 2006). The RMSEA value was calculated as 0,06 and the RMR value was calculated as 0,05 . Being value of RMSEA less than 0.08 is regarded as a good consistency (Brown, 2006; Browne \& Cudeck, 1993; Jöreskog and Sörbom, 1993).

Table 2. Confirmatory factor analysis results

\begin{tabular}{llllllllll}
\hline Scale & $x^{2} / s d$ & CFI & GFI & AGFI & NFI & NNFI & RFI & RMSEA & RMR \\
\hline Self- & 2.51 & 0.95 & 0.89 & 0.86 & 0.92 & 0.95 & 0.95 & 0.06 & 0.05 \\
Efficacy & & & & & & & & & \\
\hline
\end{tabular}

Figure 1 shows the standardized regression coefficients for the implicit dependent variable for each item. Regression coefficients for the items of academic skill subscale of the self-efficacy scale ranged from .48 to .60 ; social skills subscale ranged from .41 to .61 and emotional skills subscale ranged from .52 to .71 . This indicates that item correlations vary between .41 and .71; when assessed for all items on the scale. When the reliability coefficient of the scale was examined, the cronbach alpha value was found to be high with .88 . 


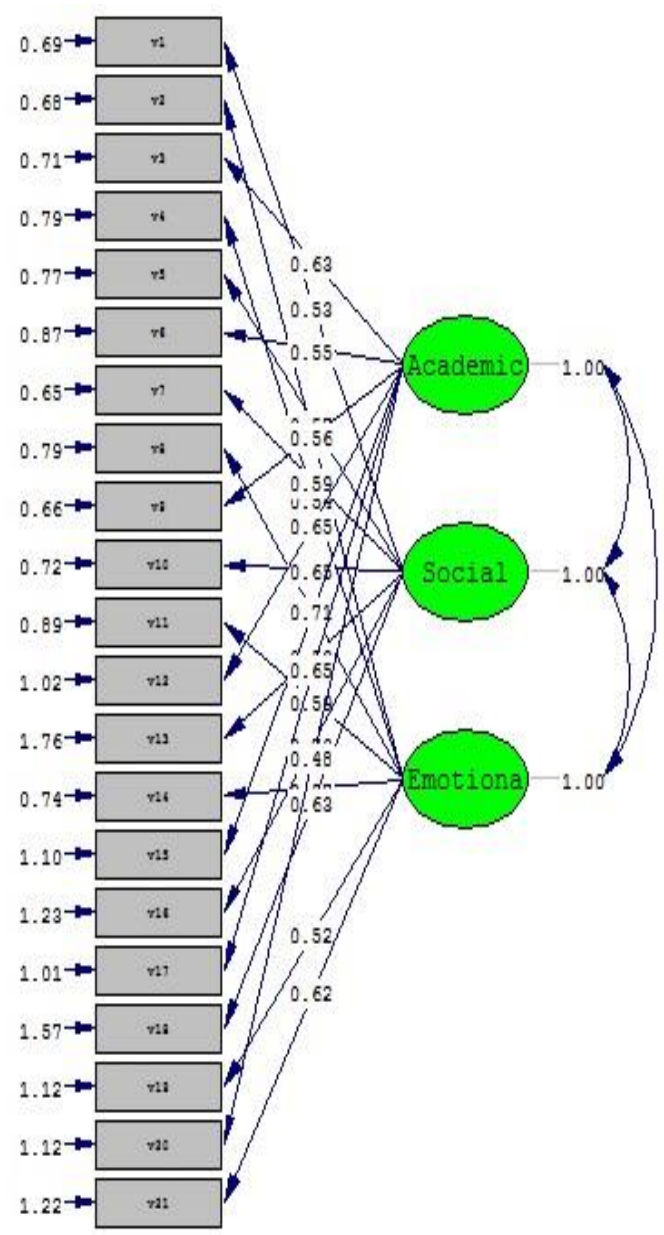

Figure 1. Confirmatory factor analysis diagram

\section{Findings about the Metacognition Scale}

When the findings of the confirmatory factor analysis made to test the correspondence with the original structure on the studied sample group of the metacognition scale were examined, $x^{2} / s d$ ratio was found $1.41\left(x^{2} / s d=534.06 / 377\right)$. Looking at the ratio of degrees of freedom with Chi-Square, it is seen that it has a value of under 3 and thus this value indicates a good consistency value (Hooper, Coughlan ve Mullen, 2008; Schermelleh-Engel, Moosbrugger ve Müller, 2003). Other consistency index values calculated with CFA are as follows: CFI: 0.99; GFI: 0.91; AGFI: 0.89; NFI: 0.93; NNFI: 0.95; RFI: 0.94. When these values are close to 1 , it is considered as a acceptable consistency (Baumgartner \& Homburg, 1996; Bentler, 1980; Bentler \& Bonett, 1980; Marsh, Hau, Artelt, Baumert \& Peschar, 2006). The RMSEA value was calculated as 0.03 and the RMR value as 0.02 . These values are considered to be in perfect consistency (Brown, 2006; Browne \& Cudeck, 1993; Jöreskog and Sörbom, 1993).

Table 3. Confirmatory factor analysis results

\begin{tabular}{llllllllll}
\hline Scale & $x^{2} / s d$ & CFI & GFI & AGFI & NFI & NNFI & RFI & RMSEA & RMR \\
\hline Metacognition & 1.41 & 0.99 & 0.91 & 0.89 & 0.93 & 0.95 & 0.94 & 0.03 & 0.02 \\
\hline
\end{tabular}


64 THE SELF-EFF ICACY AS PREDICTORS OF THE METACOGNITION AWARENESS IN CHILDREN

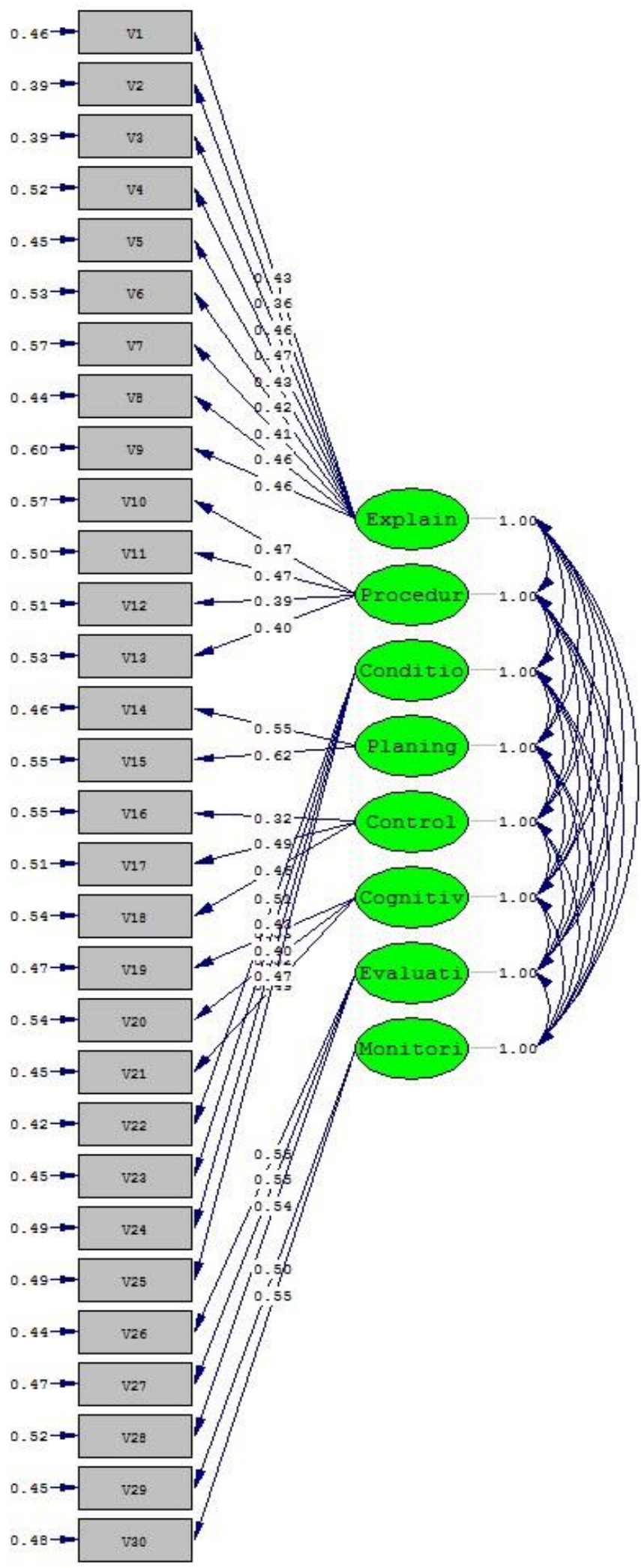

Figure 2. Confirmatory factor analysis diagram 
When figure 2 was examined, it is seen that the standardized regression coefficients on the implicit dependent variable of each item. The regression coefficients for the items of explanatory knowledge subscale of the metacognition scale ranged from .36 to .46; the methodological knowledge subscale ranged from .39 to .47; the conditional knowledge subscale ranged from .40 to .47; the planning subscale ranged from .55 to .62 ; the selfcontrol subscale ranged from .32 to .48; cognitive strategies ranged from .40 to .47 ; selfassessment subscale ranged from .55 to .54 ; and self-assessment subscale ranged from .50 to .55. This indicates that item correlations vary between .36 and .62 when assessed for all items on the scale. When the reliability coefficient of the scale was examined, the cronbach alpha value was found to be high with .92 .

\section{Findings Related to Metacognition Awareness and Self-Efficacy}

Pearson's correlation coefficient was examined to determine the relationship between children's metacognition awareness and self-efficacy, and the findings were presented in Table 4.

Table 4. Simple correlations between children's metacognition awareness and self-efficacy

\begin{tabular}{|c|c|c|c|c|c|c|c|c|c|}
\hline F. & MC. & E.K. & M.K. & C.K. & P. & S.C. & C.S. & S.A. & S.M. \\
\hline SE. & $.70^{\prime \prime \prime}$ & $.66^{\prime \prime}$ & $.54^{\prime \prime \prime}$ & $.58^{\prime \prime}$ & $.40^{\prime \prime}$ & $.53^{n+1}$ & $.53^{\mathrm{m}}$ & .550 & $.47^{\prime \prime}$ \\
\hline A. & $.65^{* *}$ & $.65^{* *}$ & $49^{* *}$ & $.54^{* * *}$ & $.36^{* * *}$ & $.48^{* * *}$ & $.48^{* *}$ & $.494^{* *}$ & $.42^{\text {*** }}$ \\
\hline S. & $.61^{* *}$ & $.59^{* *}$ & $48^{* *}$ & $.51^{* *}$ & $.30^{* *}$ & $.46^{* *}$ & $.44^{* *}$ & $.496^{* * *}$ & $.41^{* *}$ \\
\hline D. & $.54^{* *}$ & $.47^{* *}$ & $41^{* *}$ & $.44^{* *}$ & $.37^{* *}$ & $.41^{* *}$ & $.43^{* *}$ & $.426^{* * *}$ & $.39^{* * *}$ \\
\hline
\end{tabular}

(Factors:F; Self-efficacy:SE; $\quad$ Academic:A.; Social:S.; Emotional:D; Metacognition:MC.; Explanatory Knowledge:E.K.; Methodological Knowledge:M.K.; Conditional Knowledge: C.K.; Planning:P.; SelfControl:S.C.; Cognitive Strategies:C.S.; Self-Assessment:S.A.; Self-Monitoring:S.M.; **p<.01)

It is seen that there is a high correlation as positive between metacognition awareness and self-efficacy in children $(r=.698)$ when metacognition awareness and self-efficacy of children are examined in table 3 . In addition, it is seen that the relationship between the subfactors of the metacognition scale and the sub-factors of the self-efficacy scale change between medium and high levels. Multiple regression analysis was conducted to examine self-efficacy as a predictor of children's metacognition awareness and findings were presented in Table 5.

Table 5. Findings of regression analysis of self-efficacy as a predictor of children's metacognition awareness

\begin{tabular}{llllllll}
\hline Variable & $B$ & $S . H$. & $\beta$ & $T$ & $p$ & Binary & Partial \\
\hline Constant & 33.60 & 3.40 & - & 9.89 & .00 & - & - \\
Academic & 1.15 & .15 & .39 & 7.47 & .00 & .65 & .37 \\
Social & .67 & .16 & .24 & 4.35 & .00 & .61 & .23 \\
Emotional & .47 & .12 & .19 & 3.94 & .00 & .54 & .21 \\
\hline$R=.71 R^{2}=.50$ & $F=116.32$ & & & & & &
\end{tabular}

Academic, social and emotional variables with subscales of self-efficacy have a high and significant relationship with children's metacognition skill scores $\left(R=.71 ; R^{2}=.50\right.$; $p<.01)$. Academic, social and emotional variables account for about $51 \%$ of the total variance in metacognition awareness. When the standardized regression coefficient $(\beta)$ and $t$ values are examined, it can be said that in order of relative importance; academic, social and emotional skills are a significant predictor of metacognition awareness.

\section{Discussion and Conclusion}

In the first sub-problem of the study; DFA analysis and cronbach alpha values for the construct validity and reliability of "The Self-Efficacy Scale for Children" and "The 

CHILDREN

Metacognition Scale" were examined on the sample group study. For the self-efficacy scale, the $x^{2} / s d$ ratio of consistency index values calculated with DFA was found 2.51 $\left(x^{2} / s d=467.93 / 186\right)$. Other consistency index values calculated with DFA are determined as 0.95 for the CFI; 0.89 for the GFI; 0.86 for the AGFI; 0.92 for the NFI; 0.95 for the NNFI and 0.94 for the RFI. The RMSEA value was found 0.06 and the RMR value was found 0.05; while the cronbach alpha value was found .88. The consistency index values in DFA made by Telef and Karaca (2012) were found $x^{2} / s d=614.68 / 186=3.305$; RMSEA=.049; $\mathrm{NFI}=.95 ; \mathrm{CFI}=.96 ; \mathrm{GFI}=.94$ and $\mathrm{RMSR}=.066$; while the cronbach alpha coefficient was found as 0.86 . For the metacognition scale, while the $x^{2} / s d$ ratio of the consistency index values obtained from the DFA analysis on the coherence and reliability with the original structure on the sample group studied was found 1.41; other consistency index values calculated with DFA are as follows: 0.99 for CFI; 0.91 for GFI; 0.89 for AGFI; 0.93 for the NFI; 0.95 for the NNFI and 0.94 for the RFI. In addition, the RMSEA value was calculated as 0.03 and the RMR as 0.02. The Cronbach alpha value was found as .92. In the "Metacognition Scale" by Y1ldz et al. (2009), these values were found for $x^{2}=1181.63$, $\mathrm{sd}=375, \mathrm{RMSEA}=0.07, \mathrm{GFI}=0.84, \mathrm{AGFI}=0.81, \mathrm{CFI}=0.89, \mathrm{NFI}=0.85$ and $\mathrm{RMR}=0.05$ and the cronbach alpha value was found as .96. In the direction of these findings, it can be said that the measuring instruments are valid and reliable on the sample group studied.

In the second sub-problem of the study; when findings related to the relationship between metacognition awareness and self-efficacy of children are examined, it is seen that children's metacognition awareness are highly correlated with self-efficacy. Self-efficacy which includes the beliefs of the ability of children to cope with the problems they faced, the ability to cope with new situations where effort is necessary, having the ability of organizing, practicing and controlling on their work (Luszczynska, Gutierrez-Dona and Schwarzer, 2005; Scholz, Dona, Sud and Schwarzer, 2002, Eccles and Wigfield, 2002) and metacognition awareness which includes planning, comprehension and self-evaluation (Açıköz, 2000), must have a relationship between each other. Because in the expectation of competence, the child believes that he can accomplish something. This belief is accompanied by the development of metacognition awareness in children. Through their metacognition awareness, the children evaluate whether they can be successful; decide what steps to solve the problem, observe how actions progress, and transfer their experiences to subsequent actions (Gourgey, 1998). Therefore, it seems normal to have a high level of relationship between metacognition awareness and self-efficacies of children. Smith (2002) states that strengthening self-efficacy beliefs is based on direct personal experiences and that success is often attributed to one's own efforts and skills. From this point on, making meaningful learning and using metacognition awareness that include cognitive process skills such as understanding, evaluating, and controlling what they learn for children, affect also the selfefficacy (Georghiades, 2004; Nietfeld, Cao and Osborne, 2005; Pintrich, 2002; Schraw and Moshman, 1995). When investigating the researches, on one hand, it is seen that metacognition awareness have improved the success (Çakıroglu, 2007; Özsoy, 2008) and motivation (Demir-Gülşen, 2000); has developed self-control skills, has improved the way of obtaining knowledge and provided using information (Ciardiello, 1998) and has improved the ability of problem solving (Howard, McGee, Shia and Namsoo, 2000). On the other hand, self-efficacy has an impact on problem solving and goal setting (Pajares, 2002; Schunk, 1981, 1982), has ensured achievements with high levels for children have selfefficacy. Children need to actively use metacognition awareness to grow successful, to have high quality of life, to solve potential problems, to develop strategies, and to be selfconfident and patient children in implementing these strategies.

As the sub-dimensions of the self-efficacy scale, academic, social and emotional selfefficacy were found to be important predictors of metacognition awareness, when the selfefficacy as a predictor of metacognition awareness was examined in the third sub-problem of the study. According to the research by Clause, Delbridge, Schmidt, Chan and Jennings (2001) children with high self-efficacy use metacognition strategies. They also modeled the relationship between self-efficacy, metacognition, and achievement; and in the model of selfefficacy and achievement they have reached the finding that they are mediated by 
metacognition awareness. Researchers have stated that self-efficacy, behavior modification and outcomes are highly correlated with each other; and self-efficacy is an excellent predictor of behavior (Pajares, 2002; Legg and Locker, 2009). Bassi et al. (2007) reported that children with higher self-efficacy have more academic purposes and efforts. The metacognition awareness mediates the child to think and recognize about his cognitive structure for the correct structuring of knowledge. In order for this process to work, the child must be able to trust and believe in himself. Bandura (2000) stated that metacognition awareness is related to self-efficacy and that the development of children's academic and other skills is carried to higher levels by the interaction of these two factors. When the researches are examined, it has been pointed out that children's self-efficacy beliefs have positive effects on metacognition awareness (Houtveen, Van De Grift \& Creemers, 2004; Den Brok, Brekelmans \& Wubbels, 2004; Thoonen, Sleegers, Pettsma \& Oort, 2011). These findings are consistent with this study. In conclusion, the development of self-efficacy in children ensures that the child is highly self-confident and that he is aware of his/her abilities, as well as it improves the abilities of the child's metacognition awareness, positive approach to learning and to cope with difficulties (Cera, Mancini \& Antonietti, 2013). The development of metacognition awareness and self-efficacy in children should be emphasized by parents and educators. Experimental studies can be carried out by developing training programs on about the self-efficacy and the development of the metacognition awareness. The relationship between metacognition awareness and self-efficacy with other variables can be examined.

\section{References}

Açıkgöz, K. Ü. (2000). Active learnig and teaching. (3. Edition). İzmir: Kanyılmaz Press.

Balcikanli, C. (2011). Metacognitive awareness inventory for teachers (MAIT). Electronic Journal of Research in Educational Psychology, 9(3), 1309-1332.

Bandura, A. (1993). Perceived self-efficacy in cognitive development and functioning. Educational Psychologist, 28, 117-148. doi:10.1207/s 15326985ep2802_3.

Bandura, A. (2000). Self-efficacy. In A. E. Kazdin (Ed.), Encyclopedia of psychology (pp. 212 -213). New York: Oxford University Press.

Bassi, M., Steca, P., Delle Fave, A., \& Caprara, G. V. (2007). Academic self-efficacy beliefs and quality of experience in learning. Journal of Youth and Adolescence, 36(3), 301-312.

Baumgartner, H., \& Homburg, C. (1996). Applications of structural equation modeling in marketing and consumer research: A review. International Journal of Research in Marketing, 13(2), 139161.

Bentler, P.M. (1980). Multivariate analysis with latent variables: Causal modeling. Annual Review of Psychology, 31, 419-456.

Bentler, P.M., \& Bonett, D.G. (1980). Significance tests and goodness of fit in the analysis of covariance structures. Psychological Bulletin, 88, 588-606.

Brown, T. A. (2006). Confirmatory factor analysis for applied research. New York, NY: Guilford.

Browne, M.W., \& Cudeck, R. (1993). Alternative ways of assessing model fit. In: Bollen, K.A., \& Long, J.S. (Eds.), Testing structural equation models (pp. 136-162). Beverly Hills, CA: Sage

Büyüköztürk, Ş. (2010). Handbook of data analysis for the social sciences. Ankara: Pegem.

Cera, R., Mancini, M., \& Antonietti, A. (2013). Relationships between metacognition, self-efficacy and self-regulation in learning. Journal of Educational, Cultural and Psychological Studies (ECPS Journal), 4(7), 115-141.

Cheng, E. C. K. (2011). The role of self-regulated learning in enhancing learning performance. The International Journal of Research and Review, 6(1), 1-16.

Ciardiello, A. V. (1998). Did you ask a good question today? Alternative cognitive and metacognition staretgies. Journal of Adolescent \& Adult Literacy, 42(3), 210.

Clause, C. S., Delbridge, K., Schmitt, N., Chan, D., \& Jennings, D. (2001). Test preparation activities and employment test performance. Human Performance, 14(2), 149-167.

Cohen, L., Manion, L., \& Morrison, K. (2000). Research methods in education. London New York: Routledge Falmer. 

CHILDREN

Coutinho, S. (2008). Self-efficacy, metacognition, and performance. North American Journal of Psychology, 10(1), 165.

Çakıroğlu, A. (2007). The effect of metacognitive strategy training on improving the achıvement level of students having low achievement levels of reading comprehension. Doctoral Thesis. Gazi University, Institute for Educational Science, Ankara.

Demir-Gülşen, M. (2000). A model to investigate probability and mathematics achievement İn terms of cognitive, metacognitive and affective variables. Master Thesis. Boğaziçi University, The Institute for Graduate Studies in Science and Engineering, İstanbul.

Den Brok, P., Brekelmans, M., \& Wubbels, T. (2004). Interpersonal teacher behaviour and student outcomes. School Effectiveness and School Improvement, 15(3-4), 407-442.

Eccles, J. S., \& Wigfield, A. (2002). Motivational beliefs, values, and goals. Annual Review of Psychology, 53(1), 109-132.

Flavell, J. H. (1976). Metacognitive aspects of problem solving. In L.B. Rensnick (Ed.), (pp. 231235). Hillsdale, NJ: John Wiley.

Flavell, J. H. (1979). Metacognition and cognitive monitoring: A new area of cognitive developmental inquiry. American Psychologist, 34, 906-911.

Floyd, F. J., \& Widaman, K. F. (1995). Factor analysis in the development and refinement of clinical assessment instruments. Psychological Assessment, 7(3), 286.

Gall, J., Gall, M. D., \& Borg, W. R. (1999). Appling educational research. New York: Longman.

Gay L. R., 1987. Educational research compentencies for analysis and application. New York: Macmillan Publishing Company.

Georghiades, P. (2004). Making pupils' conceptions of electricity more durable by means of situated metacognition. International Journal of Science Education, 26(1), 85-99.

Gourgey, A. F. (1998). Metacognition in basic skills instruction. Instructional Science, 26(1), 81-96.

Hooper, D., Coughlan, J. \& Mullen, M.(2008). Structural equation modelling: Guidelines for determining model fit. Electronic Journal of Business Research Methods, 6(1), 53-60.

Houtveen, A. A. M., Van de Grift, W. J. C. M., \& Creemers, B. P. M. (2004). Effective school improvement in mathematics. School Effectiveness and School Improvement, 15(3-4), 337-376.

Howard, B. C., McGee, S., Shia, R., \& Hong, N. S. (2000). Metacognitive self-regulation and problem-solving: Expanding the theory base through factor analysis. The Annual Meeting of the American Educational Research Association (New Orleans, LA, April 24- 28).

Jöreskog, K. G., \& Sörbom, D. (1993). LISREL 8: Structural equation modeling with the SIMPLIS command language. Scientific Software International.

Kaplan, A., \& Duran, M. (2016). Ortaokul öğrencilerinin matematik dersine çalşma sürecinde üstbilişsel farkındalık düzeylerinin karşılaştırılması. Bayburt Eğitim Fakültesi Dergisi, 10(2), 417-445.

Kline, R. B. (2005). principles and practice of structural equation modeling (2nd ed.). New York: Guilford.

Legg, A. M., \& Locker Jr, L. (2009). Math performance and its relationship to math anxiety and metacognition. North American Journal of Psychology, 11(3), 471-486.

Luszczynska, A., Gutiérrez-Doña, B., \& Schwarzer, R. (2005). General self-efficacy in various domains of human functioning: Evidence from five countries. International Journal of Psychology, 40(2), 80-89.

Marsh, H.W., Hau, K.T., Artelt, C., Baumert, J., \& Peschar, J.L. (2006). OECD's brief self-report measure of educational psychology's most useful affective constructs: Cross-cultural, psychometric comparis ons across 25 countries. International Journal of Testing, 6(4), 311-360.

Moores, T. T., Chang, J. C. J., \& Smith, D. K. (2006). Clarifying the role of self-efficacy and metacognition as predictors of performance: construct development and test. ACM SIGMIS Database, 37(2-3), 125-132.

Muris, P. (2001). "A brief questionnaire for measuring self-efficacy in youths". Journal of Psychopathology and Behavioral Assessment, 23, 145-149.

Nietfeld, J. L., Cao, L., \& Osborbe, J. W. (2005). Metacognitive monitoring accuracy and student performance in the postsecondary classroom. The Journal of Experimental Education, 74(1), 728.

Özsoy, G. (2008). Metacognition. The Journal of Turkish Educational Sciences, 6(4), 713-740. 
Pajares, F. (2002). Gender and perceived self-efficacy in self-regulated learning. Theory into Practice, 41(2), 116-125.

Pintrich, P. R. (2002). The role of metacognitive knowledge in learning, teaching, and assessing. Theory into Practice, 41(4), 219-225.

Ridlo, S., \& Lutfiya, F. (2017). The Correlation between metacognition level with self-efficacy of biology education college students. In Journal of Physics: Conference Series, 824(1), 012067. IOP Publishing.

Scholz, U., Doña, B. G., Sud, S., \& Schwarzer, R. (2002). Is general self-efficacy a universal construct? Psychometric findings from 25 countries. European Journal of Psychological Assessment, 18(3), 242.

Schraw, G., Crippen, K. J., \& Hartley, K. (2006). Promoting self-regulation in science education: Metacognition as part of a broader perspective on learning. Research in Science Education, 36(12), 111-139.

Schraw, G., \& Moshman, D. (1995). Metacognitive theories. Educational Psychological Review, 7, 351-371.

Schunk, D. H. (1981). Modeling and attributional effects on children's achievement. A self-efficacy analysis. Journal of Educational Education, 73, 93-105.

Schunk, D. H. (1982). Effects of effort attributional feedback on children's achievement: Self-efficacy analysis. Journal of Educational Psychology, 74, 548-556.

Smith, M. S. (2002). Using the social cognitive model to explain vocational interest in information technology. Information Technology, Learning, and Performance Journal, 20, 1-9.

Telef, B. B., \& Karaca, R. (2012). The self efficacy scale for children; A validity and reliability study. Buca Faculty of Education Journal, 32, 169-187.

Thomas, G. P., \& McRobbie, C. J. (2001). Using a metaphor for learning to improve students' metacognition in the chemistry classroom. Journal of Research in Science Teaching, 38(2), 222259.

Thoonen, E. E., Sleegers, P. J., Peetsma, T. T., \& Oort, F. J. (2011). Can teachers motivate students to learn? Educational Studies, 37(3), 345-360.

Ylldı, E., Akpınar, E., Tatar, N., \& Ergin, O. (2009). Exploratory and confirmatory factor analysis of the metacognition scale for primary schoolstudents. Educational Sciences: Theory and Practice, 9(3), 1591-1604.

Zakeri, A., Rahmany, R., \& Labone, E. (2016). Teachers' Self-and Collective Efficacy: The Case of Novice English Language Teachers. Journal of Language Teaching and Research, 7(1), 158167. 
